\title{
Character Association and Path Analysis Study in Determinate Tomato (Solanum lycopersicum L.)
}

\author{
Meera Rojalin ${ }^{1}$, P. Tripathy ${ }^{1 *}$, G.S. Sahu ${ }^{1}$, S.K. Dash ${ }^{2}$, D. Lenka ${ }^{3}$, \\ B. Tripathy ${ }^{1}$ and P. Sahu ${ }^{1}$ \\ ${ }^{1}$ Department of Vegetable Science, College of Agriculture, OUAT, Bhubaneswar, \\ Odisha, India \\ ${ }^{2}$ (Vegetable Agronomist), AICRP on Vegetable Crops, OUAT, Bhubaneswar, Odisha, India \\ ${ }^{3}$ Department of Plant Breeding and Genetics, College of Agriculture, OUAT, Bhubaneswar, \\ Odisha, India \\ *Corresponding author
}

\section{A B S T R A C T}

\begin{tabular}{|l|}
\hline Ke y w o r d s \\
$\begin{array}{l}\text { Determinate tomato, } \\
\text { Character association, } \\
\text { path analysis and yield } \\
\text { attributes }\end{array}$ \\
\hline Article Info \\
\hline $\begin{array}{l}\text { Accepted: } \\
10 \text { October } 2018 \\
\text { Available Online: } \\
\text { 10 November } 2018\end{array}$ \\
\hline
\end{tabular}

Field experiment was conducted at All India Co-ordinated Research Project on Vegetable Crops, OUAT, Bhubaneswar, Odisha, India during rabi, 2017-18 to study the correlation and path coefficient analysis in determinate tomato for improvement of desirable genotype (s) for fruit yield and yield attributes. Eighteen genotypes were evaluated by adopting RBD replicated thrice. At both phenotypic and genotypic level, marketable fruit yield plant $^{-1}$ was positive and significantly correlated with plant height $(0.45$ and 0.31$)$ and primary branches plant ${ }^{-1}(0.51$ and 0.38$)$. Similarly, traits like average fruit weight $(0.334)$, number of locules $(0.204)$, fruit length $(0.143)$, \% of fruit set $(0.126)$, flowers cluster ${ }^{-1}$ $(0.106)$, days to fruit set $(0.102)$, fruits plant $^{-1}(0.096)$, primary branches plant $^{-1}(0.070)$ and plant height at final harvest (0.009) in order of merits imposed positive direct effect on marketable fruit yield plant ${ }^{-1}$. Hence on selecting these characters may give varieties with high yield and better quality fruits.

\section{Introduction}

Tomato (Solanum lycopersicum L.) is one of the most important vegetable crop grown throughout the world because of its wider adaptability, high yielding capacity and suitability of variety to be used in fresh as well as processing industries (He et al., 2003; Nwosu et al., 2014). It belongs to the family Solanaceae. Tomato is cultivated in all the three major climates of temperate, sub-tropical and tropical regions of the world, under both open and protected conditions as well. Apart from contributing nutritive elements, colour and flavour to the diet, tomatoes are also act as a valuable source of antioxidants or chemoprotective compounds and may thus be termed a "functional food" (Ranieri et al., 2004). Indian yield levels $\left(24.2\right.$ tha $\left.^{-1}\right)$ are far below the world average of 37 tha $^{-1}$ (NHB, 2016). Low yield increases the cost and the risk of growing tomatoes. Therefore, farmer's income is decreased. Yield is a quantitative character controlled by many genes. The consideration 
of yield components in selection is based on the assumption that a strong positive correlation exists between yield and yield components and that these component characters have higher heritability than yield (Lungu, 1978) and is very useful for plant breeder in developing commercial variety or hybrid. However, it does not give an exact picture of relative importance of direct and indirect effects of various yield attributes.

Under such circumstances, the technique of path coefficient analysis was developed by Wright (1921) and demonstrated by Dewey and Lu (1959) as a means of separating direct and indirect contribution of various traits. Therefore, it is necessary to study the path coefficient analysis to find out the characters which directly or indirectly contributes to yield. Thus, keeping above situations in view, the present research work was conducted to study the correlation and path coefficient analysis of eighteen genotypes of determinate tomato for fourteen characters.

\section{Materials and Methods}

The experiment was carried out at All India Co-ordinated Research Project on Vegetable Crops, OUAT, Bhubaneswar, during rabi, 2017-18 with 18 tomato genotypes. The experiment was laid out in Randomized Block Design (RBD) with three replications. In each replication, each entry was grown in five rows having six plants in each row spaced $60 \mathrm{~cm}$ between rows and $45 \mathrm{~cm}$ between plants. From randomly selected 5 plants per each plot observations were recorded for fourteen characters viz., plant height $(\mathrm{cm})$, primary branches plant ${ }^{-1}$, intermodal length $(\mathrm{cm})$, days to first flowering., number of flowers cluster ${ }^{-1}$, $\%$ of fruit set, days to fruit set, average fruit weight $(\mathrm{g})$, fruit length $(\mathrm{cm})$, fruit girth $(\mathrm{cm})$, pericarp thickness $(\mathrm{cm})$, number of locules, fruits plant $^{-1}$, marketable fruit yield plant $^{-1}$ (kg).

\section{Results and Discussion}

In general, correlation studies are highly beneficial in selecting superior genotypes for any population improvement programme (Robinson, 1966). It is highly essential to judge the interrelationship of the quantitative characters through correlation study both at genotypic and phenotypic level for an effective selection in developing a new genotype. All the genotypic and phenotypic correlation coefficient between fruit yield and yield components is given in Table 1 and 2 .

\section{Plant height}

Plant height showed positive and significant correlation with marketable fruit yield plant $^{-1}$ (0.45 and 0.31), internodal length (0.67 and $0.62), \%$ of fruit set (0.47 and 0.29$)$, days to fruit set (0.60 and 0.39), average fruit weight (0.53 and 0.41$)$ and fruit girth (0.51 and 0.41) at both phenotypic and genotypic level. This indicates that marketable fruit yield plant ${ }^{-1}$ was increased with the increase of plant height. This result is in conformation with the findings of Prashanth et al., (2008), Ara et al., (2009), Monamodi et al., (2013) and Kumar et al., (2014). On the other hand, this character had significant and negative correlation with number of flowers cluster ${ }^{-1}(-0.43$ and -0.35$)$ which indicated that this trait was increased with decrease of plant height.

\section{Primary branches plant ${ }^{-1}$}

Primary branches plant $^{-1}$ was found to be significantly and positively associated with marketable fruit yield plant ${ }^{-1}(0.51$ and 0.38$)$. This result is in agreement with the findings of Rawat et al., (2017). This character also significantly and positively associated with pericarp thickness only at genotypic level (0.27). It indicated this trait was increased with the increase of pericarp thickness. 


\section{Internodal length}

It was noticed that internodal length was positively and significantly correlated with days to fruit set (0.43 and 0.34$)$, average fruit weight (0.53 and 0.48), fruit girth (0.52 and $0.48)$ and number of locules (0.42 and 0.41) at both phenotypic and genotypic level.

This character had significant and negative correlation with days to $1^{\text {st }}$ flowering $(-0.39$ and -0.33$)$ and fruits plant ${ }^{-1}(-0.34$ and -0.29$)$.

\section{Days to $1^{\text {st }}$ flowering}

Days to $1^{\text {st }}$ flowering exhibited positive and significant correlation with days to fruit set (0.33 and 0.32 ) and $\%$ of fruit set (0.33) at genotypic level. This trait had significant negative association with number of flowers cluster $^{-1}(-0.32)$ and number of fruits plant ${ }^{-1}$ ($0.30)$ at genotypic level.

\section{Number of flowers cluster ${ }^{-1}$}

It had negative and significant association with $\%$ of fruit set $(-0.84$ and -0.47$)$, days to fruit set $(-0.40$ and -0.35$)$, fruit length $(-0.43$ and -0.39$)$, fruit girth (-0.65 and -0.57$)$ and number of locules (-0.54 and -0.50) which indicates number of flowers cluster ${ }^{-1}$ was decreased with the increase of these traits. Result for number of locules is in accordance with Shankar et al., (2014).

\section{$\%$ of fruit set}

It was found that $\%$ of fruit set was positively and significantly correlated with days to fruit set (0.28 and 0.30).

It was also positively associated with characters like fruit length (0.28) at phenotypic level, but with fruit girth (0.43) and number of fruits plant ${ }^{-1}(0.47)$ at genotypic level whereas, it had a negatively association with average fruit weight (-0.36) only at genotypic level. Meena and Bahadur, 2015 had also reported similar result for the character number of fruits plant ${ }^{-1}$.

\section{Days to fruit set}

Days to fruit set was positively and significantly correlated with average fruit weight $(0.45$ and 0.34$)$ and fruit girth $(0.44$ and 0.28 ) both at genotypic and phenotypic level, but with fruit length (0.38) only at genotypic level.

\section{Average fruit weight}

It was observed that average fruit weight was positively and significantly correlated with fruit girth (0.34 and 0.30) which indicates that fruit weight was increased with increase of fruit girth. Similar result was observed by Rawat et al., (2017). It had also positive association with pericarp thickness (0.29) only at genotypic level but it was negatively and significantly correlated with number of fruits plant $^{-1}(-0.64$ and -0.60$)$. This result was in line with findings of Kumar et al., (2013).

\section{Fruit length}

Fruit length had positive and significant correlation with fruit girth $(0.78$ and 0.78$)$ and number of locules (0.51 and 0.43$)$ whereas, it had negative and significant correlation with fruits plant ${ }^{-1}(-0.33$ and -0.30$)$. This negative association result is similar with the findings of Hidayatullah et al., (2008).

\section{Fruit girth}

It was found from the correlation coefficient result that fruit girth was positively and significantly correlated with number of locules (0.83 and 0.73 ) but significantly negatively associated with fruits $\operatorname{plant}^{-1}(0.39)$ at genotypic level. 
Table.1 Genotypic correlation coefficient among 14 characters of 18 genotypes of determinate tomato

\begin{tabular}{|c|c|c|c|c|c|c|c|c|c|c|c|c|c|c|}
\hline & & 2 & 3 & 4 & 5 & 6 & 7 & 8 & 9 & 10 & 11 & 12 & 13 & 14 \\
\hline 1 & $\mathbf{G}$ & 0.25 & $0.67 * *$ & -0.06 & $-0.43 * *$ & $0.47 * *$ & $0.60 * *$ & $0.53 * *$ & 0.15 & $0.51 * *$ & -0.16 & 0.26 & -0.03 & $0.45 * *$ \\
\hline 2 & $\mathbf{G}$ & & 0.18 & -0.03 & 0.02 & -0.17 & -0.24 & 0.08 & -0.11 & 0.15 & $0.27 *$ & 0.23 & 0.11 & $0.51 * *$ \\
\hline 3 & $\mathbf{G}$ & & & $-0.39 * *$ & -0.26 & -0.06 & $0.43 * *$ & $0.53 * *$ & 0.13 & $0.52 * *$ & 0.05 & $0.42 * *$ & $-0.34 *$ & 0.08 \\
\hline 4 & G & & & & $-0.32 *$ & $0.33^{*}$ & $0.33^{*}$ & -0.09 & 0.24 & 0.03 & 0.18 & -0.11 & $-0.30 *$ & 0.07 \\
\hline 5 & $\mathbf{G}$ & & & & & $-0.84 * *$ & $-0.40 * *$ & -0.17 & $-0.43 * *$ & $-0.65 * *$ & 0.008 & $-0.54 * *$ & 0.21 & -0.26 \\
\hline 6 & G & & & & & & $0.28 *$ & $-0.36 * *$ & 0.50 & $0.43 * *$ & -0.16 & 0.24 & $0.47 * *$ & 0.14 \\
\hline 7 & $\mathbf{G}$ & & & & & & & $0.45 * *$ & $0.38 * *$ & $0.44 * *$ & 0.08 & 0.19 & -0.14 & 0.12 \\
\hline 8 & $\mathbf{G}$ & & & & & & & & 0.12 & $0.34^{*}$ & $0.29 *$ & 0.22 & $-0.64 * *$ & 0.12 \\
\hline 9 & G & & & & & & & & & $0.78 * *$ & -0.02 & $0.51 * *$ & $-0.33^{*}$ & 0.11 \\
\hline 10 & $\mathbf{G}$ & & & & & & & & & & 0.07 & $0.83 * *$ & $-0.39 * *$ & 0.23 \\
\hline 11 & G & & & & & & & & & & & 0.10 & $-0.30 *$ & -0.07 \\
\hline 12 & G & & & & & & & & & & & & -0.23 & $0.39 * *$ \\
\hline 13 & G & & & & & & & & & & & & & 0.20 \\
\hline
\end{tabular}

Table.2 Phenotypic correlation coefficient among 14 characters of 18 genotypes of determinate tomato

\begin{tabular}{|c|c|c|c|c|c|c|c|c|c|c|c|c|c|c|}
\hline & & 2 & 3 & 4 & 5 & 6 & 7 & 8 & 9 & 10 & 11 & 12 & 13 & 14 \\
\hline 1 & $\mathbf{P}$ & 0.22 & $0.62 * *$ & -0.08 & $-0.35^{* *}$ & $0.29 *$ & $0.39 * *$ & $0.41 * *$ & 0.15 & $0.41^{* *}$ & -0.09 & 0.24 & 0.01 & $0.31 *$ \\
\hline 2 & $\mathbf{P}$ & & 0.17 & -0.05 & -0.002 & 0.002 & -0.11 & 0.08 & -0.09 & 0.14 & 0.22 & 0.22 & 0.04 & $0.38 * *$ \\
\hline 3 & $\mathbf{P}$ & & & $-0.33^{*}$ & -0.24 & -0.01 & $0.34^{*}$ & $0.48 * *$ & 0.13 & $0.48^{* *}$ & 0.04 & $0.41 * *$ & $-0.29 *$ & 0.05 \\
\hline 4 & $\mathbf{P}$ & & & & -0.20 & 0.16 & $0.32 *$ & -0.13 & 0.14 & 0.0007 & 0.10 & -0.07 & -0.15 & -0.05 \\
\hline 5 & $\mathbf{P}$ & & & & & $-0.47 * *$ & $-0.35 * *$ & -0.14 & $-0.39 * *$ & $-0.57 * *$ & -0.04 & $-0.5 * *$ & 0.19 & -0.20 \\
\hline 6 & $\mathbf{P}$ & & & & & & $0.30^{*}$ & -0.15 & $0.28 *$ & 0.22 & -0.14 & 0.12 & 0.16 & 0.17 \\
\hline 7 & $\mathbf{P}$ & & & & & & & $0.34 *$ & 0.24 & $0.28 *$ & 0.11 & 0.16 & -0.06 & 0.12 \\
\hline 8 & $\mathbf{P}$ & & & & & & & & 0.12 & $0.30 * *$ & 0.16 & 0.18 & $-0.60 * *$ & 0.20 \\
\hline 9 & $\mathbf{P}$ & & & & & & & & & $0.78 * *$ & -0.04 & $0.43^{* *}$ & $-0.30^{*}$ & 0.09 \\
\hline 10 & $\mathbf{P}$ & & & & & & & & & & 0.005 & $0.73^{* *}$ & -0.34 & 0.14 \\
\hline 11 & $\mathbf{P}$ & & & & & & & & & & & 0.06 & -0.19 & -0.03 \\
\hline 12 & $\mathbf{P}$ & & & & & & & & & & & & -0.18 & 0.25 \\
\hline 13 & $\mathbf{P}$ & & & & & & & & & & & & & 0.17 \\
\hline
\end{tabular}

1-Plant height $(\mathrm{cm})$, 2-Primary branches plant ${ }^{-1}, 3$ - Internodal length $(\mathrm{cm}), 4$-Days to first flowering, 5-Number of flowers cluster ${ }^{-1}, 6-\%$ of fruit set, 7-Days to fruit set, 8- Average fruit weight $(\mathrm{g})$, 9- Fruit length $(\mathrm{cm}), 10$-Fruit girth $(\mathrm{cm}), 11$-Pericarp thickness $(\mathrm{cm}), 12$-Number of locules, 13-Number of fruits plant ${ }^{-1,}$ 14Marketable fruit yield plant $^{-1}(\mathrm{~kg})$, G:Genotypic level; P: Phenotypic level 
Table.3 Direct and indirect effects of component traits on yield on 18 genotypes of determinate tomato at Phenotypic level for 13 characters

\begin{tabular}{|c|c|c|c|c|c|c|c|c|c|c|c|c|c|}
\hline Character & 1 & 2 & 3 & 4 & 5 & 6 & 7 & 8 & 9 & 10 & 11 & 12 & 13 \\
\hline 1 & 0.009 & 0.002 & 0.006 & -0.001 & -0.003 & 0.003 & 0.004 & 0.004 & 0.001 & 0.004 & -0.001 & 0.002 & 0.0001 \\
\hline 2 & 0.016 & 0.070 & 0.012 & -0.003 & -0.0001 & 0.0001 & -0.008 & 0.006 & -0.006 & 0.010 & 0.015 & 0.015 & 0.003 \\
\hline 3 & -0.044 & -0.012 & -0.070 & 0.023 & 0.017 & 0.001 & -0.024 & -0.034 & -0.009 & -0.034 & -0.003 & -0.029 & 0.020 \\
\hline 4 & 0.007 & 0.004 & 0.028 & -0.085 & 0.017 & -0.013 & -0.028 & 0.011 & -0.012 & 0.0001 & -0.009 & 0.006 & 0.013 \\
\hline 5 & -0.037 & -0.0002 & -0.025 & -0.022 & 0.106 & -0.050 & -0.037 & -0.015 & -0.041 & -0.061 & -0.004 & -0.053 & 0.021 \\
\hline 6 & 0.037 & 0.0002 & -0.001 & 0.020 & -0.059 & 0.126 & 0.038 & -0.019 & 0.036 & 0.028 & -0.018 & 0.015 & 0.020 \\
\hline 7 & 0.040 & -0.011 & 0.035 & 0.033 & -0.035 & 0.031 & 0.102 & 0.035 & 0.024 & 0.029 & 0.011 & 0.016 & -0.006 \\
\hline 8 & 0.137 & 0.027 & 0.161 & -0.042 & -0.048 & -0.051 & 0.114 & 0.334 & 0.040 & 0.099 & 0.053 & 0.060 & -0.199 \\
\hline 9 & 0.021 & -0.013 & 0.019 & 0.020 & -0.055 & 0.041 & 0.034 & 0.017 & 0.143 & 0.111 & -0.006 & 0.062 & -0.043 \\
\hline 10 & -0.041 & -0.014 & -0.047 & 0.0001 & 0.057 & -0.022 & -0.028 & -0.030 & -0.077 & -0.099 & -0.0005 & -0.072 & 0.034 \\
\hline 11 & 0.007 & -0.018 & -0.004 & -0.009 & 0.003 & 0.012 & -0.009 & -0.013 & 0.004 & -0.0004 & -0.084 & -0.005 & 0.016 \\
\hline 12 & 0.049 & 0.044 & 0.083 & -0.015 & -0.102 & 0.024 & 0.032 & 0.037 & 0.088 & 0.149 & 0.012 & 0.204 & -0.038 \\
\hline 13 & 0.001 & 0.004 & -0.028 & -0.014 & 0.019 & 0.015 & -0.006 & -0.057 & -0.029 & -0.033 & -0.018 & -0.018 & 0.096 \\
\hline 14 & 0.3060 & 0.3800 & 0.052 & -0.051 & -0.199 & 0.172 & 0.117 & 0.198 & 0.092 & 0.142 & -0.034 & 0.252 & 0.172 \\
\hline Partial $\mathbf{R}^{2}$ & 0.003 & 0.027 & -0.004 & 0.004 & -0.021 & 0.022 & 0.012 & 0.066 & 0.013 & -0.014 & 0.003 & 0.051 & 0.016 \\
\hline
\end{tabular}

Residual effect: 0.448

1-Plant height $(\mathrm{cm}), 2$-Primary branches plant ${ }^{-1}, 3$ - Intermodal length (cm), 4-Days to first flowering., 5-Number of flowers cluster ${ }^{-1}, 6-\%$ of fruit set, 7-Days to fruit set, 8- Average fruit weight (g), 9- Fruit length (cm),10-Fruit girth (cm), 11-Pericarp thickness (cm), 12-Number of locules 13- Fruits plant ${ }^{-1}$, 14-Marketable fruit yield plant ${ }^{-1}(\mathrm{~kg})$. 


\section{Pericarp thickness}

Pericarp thickness had significant and negative correlation with fruits plant ${ }^{-1}(-0.30)$ at genotypic level. Similar result was reported by Hidayatullah et al., (2008).

\section{Number of locules}

It was observed that number of locules was significantly and positively correlated with marketable fruit yield plant $^{-1}(0.39)$ at genotypic level which indicated that marketable fruit yield plant $^{-1}$ was increased with the increase of number of locules. Similar results have also been reported by Agong et al., (2008), Haydar et al., (2007), Mohanty (2003), Harer et al., (2003), Mohanty (2002a), Mohanty (2002b) in tomato.

\section{Number of fruits plant ${ }^{-1}$}

Correlation coefficient revealed that number of fruits plant $^{-1}$ was significantly and negatively correlated with internodal length (0.34 and -0.29$)$, average fruit weight $(-0.64$ and -0.60$)$ and fruit length $(-0.33$ and -0.30$)$ both at genotypic and phenotypic level. Whereas, this character is significantly and negatively correlated with days to $1^{\text {st }}$ flowering (-0.30), fruit girth (-0.39) and pericarp thickness $(-0.30)$ only at genotypic level. This indicates those characters were decreased with the increase of number of fruits plant $^{-1}$. Similar negative correlation of number of fruits plant ${ }^{-1}$ with average fruit weight was found by Rawat et al., (2017). But at this level this character had shown positive and significant association with \% fruit set (0.47).

From the result of correlation coefficient analysis it was concluded that characters like plant height, primary branches plant ${ }^{-1}$ and number of locules were important correlated characters contributing towards yield in determinate tomato. Therefore, simultaneous improvement in these characters will be highly beneficial for development of desirable genotypes in tomato.

In order to obtain a desirable genotype with higher yield potential in determinate tomato, it is highly essential to study direct and indirect effects. In general, studies on path analysis of characters showed direct and indirect effects contributing towards yield of the crop. The results presented in Table 3 .

The path coefficient result showed both direct and indirect effects of component traits on marketable fruit yield plant ${ }^{-1}$ through average fruit weight (0.334) closely followed by number of locules (0.204), fruit length $(0.143), \%$ of fruit set (0.126), flowers cluster $^{-1}$ (0.106), days to fruit set (0.102), fruits plant ${ }^{-1}(0.096)$, primary branches plant ${ }^{-1}$ $(0.070)$ and plant height at final harvest (0.009). However, the study also showed negative direct path for marketable fruit yield plant $^{-1}$ with fruit girth $(-0.099)$, days to $1^{\text {st }}$ flowering (-0.085), pericarp thickness ($0.084)$ and internodal length (-0.070).Similar results of positive association have been reported by Kumar et al., (2016) for average fruit weight, number of locules and plant height at final harvest by Reddy et al., (2013) also reported similar observations for other traits like plant height, fruits plant $^{-1}$, fruit length, and fruit width. The findings confirmed the findings of Ara et al., (2009) and Monamodi et al., (2013) with respect to the direct and highest direct effect of average fruit weight on fruit yield.

The residual effect (0.448) was very low indicated that most of the important characters contributing towards yield through both direct and indirect path had been included. Similar reports of lower residual effect in determinate tomato have been 
reported by Kumar et al., (2016). They reported a residual effect of 0.6239 which showed that the characters under study contributed $99.5 \%$ variation to fruit yield. Ara et al., (2009) too reported a residual value of 0.2268 in tomato.

The characters like number of flowers cluster $1, \%$ of fruit set, days to fruit set, average fruit weight, fruit length, number of locules can be put to direct selection pressure in order to increase the yield potential because these characters have direct effect on yield of determinate tomato.

\section{References}

Agong, S.G., Schittenhelm, S. and Friedt, W. 2008. Genotypic variation of Kenyan tomato (Lycopersicon esculentum L.) germplasm. PGR Newsletter, FAO Biodiversity 123: 61-67.

Ambresh, Lingaiah, H.B., Renuka, M. and Jyothi, K. 2017. Phenotypic and Genotypic correlation coefficient studies in tomato (Solanum lycopersicum L.) for yield and quality traits. International Journal of Current Microbiology and Applied Sciences. 11: 2287-2292.

Ara, A., Narayan, R., Ahmed, N. and Khan, S. H. 2009. Genetic variability and selection parameters for yield and quality attributes in tomato. Indian Journal of Horticulture. 66(1): 73-78.

Dewey, D. and Lu, K. H. 1959. A correlation and path coefficient analysis in crested wheat grass seed production. Journal of Agronomy. 54: 515-518.

Harer, P.N., Lad, D.B. and Bhor, T.J. 2003. Correlaton and path analysis studies in tomato. Journal of Maharashtra Agricultural University. 27: 302-303.

Haydar, A., Mandal, M.A., Ahmed, M.B., Hannan, M.M., Karim, R., Razvy, M.A., Roy, U.K. and Salahin, M. 2007.
Studies on genetic variability and interrelationship among the different traits in tomato. Middle East Journal of Scientific Research 2 (3-4): 139-142.

He, C., Poysa, V., and Yu, K. 2003. Development and characterization of simple sequence repeat (SSR) markers and their use in determining relationships among Lycopersicon esculentum cultivars. Theoretical and Applied Genetics. 106, 363-373.

Hidayatullah, Jatoi, S. A, Ghafoor, A. and Mahmood, T. 2008. Path coefficient analysis of yield component in tomato (Lycopersicon esculentum Mill.), Pakistan Journal of Botany, 40(2): 627635.

Kumar, D., Kumar, R., Kumar, S., Bhardwaj, M. L., Thakur, M. C., Kumar, R., Thakur, K.S., Dogra, B. S, Vikram, A., Thakur, A. and Kumar, P. 2013. Genetic variability, correlation and path coefficient analysis in tomato, International Journal of Vegetable Science, 19: 313-323.

Lungu, M. D. 1978. Classifying winter wheat environments into adaptive zones as a basis for recommending a reduction in the number of international winter wheat performance nursery test sites M.Sc. thesis, University of Nebraska, Lincoln.

Meena, O. P. \& Bahadur V. 2015. Genetic associations analysis for fruit yield and its contributing traits of indeterminate tomato (Solanum lycopersicum L.) germplasm. Journal of Agricultural Sciences. 7(3): 148-163.

Mohanty, B.K. 2002a. Variability, heritability, correlation and path coefficient studies in tomato. Haryana Journal of Horticultural Sciences. 31 (3-4): 230-233.

Mohanty, B.K. 2002b. Studies on variability, heritability, interrelationship and path 
analysis in tomato. Annals of Agricultural Research. 23 (1): 65-69.

Mohanty, B.K. 2003. Genetic variability, correlation and path coefficient studies in tomato. Indian Journal of Agricultural Research. 37 (1): 68-71.

Monamodi, E.L., Lungu, D.M. and Fite, G.L. 2013. Analysis of fruit yield and its components in determinate tomato (Lycopersicon lycopersci) using correlation and path analysis. Botswana Journal of Agriculture and Applied Science. 9 (1): 29-40.

National Horticulture Board (nhb.gov.in)

Nwosu, D. J., Onakoya, O. A., Okere, A. U., Babatunde, A. O., and Popoola, A. F. 2014. Genetic variability and correlations in rainfed tomato (Solanum spp.) accessions in Ibadan, Nigeria. Greener Journal of Agricultural Sciences, 4(5), 211-219.

Prashanth, S.J., Jaiprakashnarayan, R.P., Mulge, Ravindra and Madalageri, M.B. 2008. Correlation and path analysis in tomato (Lycopersicon esculentum Mill.). The Asian Journal of Horticulture. 3 (2): 403-408.

Ranieri, A., Giuntini, D., Lercari, B., Soldatini, G.F. 2004. Light influence on antioxidant properties of tomato fruits. Progress in Nutrition. 6:44-49.
Rawat, M., Singh, D., Singh, N. and Kathayat, K. 2017. Character association and path coefficient analysis in tomato (Solanum lycopersicum L.). International Journal of Current Microbiology and Applied Sciences. 6 (8):1966-1972.

Reddy, B. R., Reddy, D.S., Reddaiah, K. and Sunil, N. 2013. Studies on genetic variability, heritability and genetic advance for yield and quality traits in Tomato (Solanum lycopersicum L.). International Journal of Current Microbiology and Applied Sciences. 2(9): 238-244.

Robinson, H. F. 1966. Quantitative genetics in relation to breeding on the centennial of Mendelism. Indian Journal of Genetics. 26 (A):171-177.

Shankar, A., Reddy, RVSK, Sujatha, M., Pratap, M. 2014. Genetic association analysis for yield and quality traits in tomato (Solanum lycopersicum L.), Life Sciences International Research Journal. 1(1): 78-85.

Wright, S. 1921. System of mating biometric relation between parent and offspring. Genetics. 6: 111-123.

\section{How to cite this article:}

Meera Rojalin, P. Tripathy, G.S. Sahu, S.K. Dash, D. Lenka, B. Tripathy and Sahu, P. 2018. Character Association and Path Analysis Study in Determinate Tomato (Solanum lycopersicum L.). Int.J.Curr.Microbiol.App.Sci. 7(11): 863-870. doi: https://doi.org/10.20546/ijcmas.2018.711.102 